\title{
How do education, cognitive skills, cultural and social capital account for intergenerational earnings persistence? Evidence from the Netherlands
}

Citation for published version (APA):

Büchner, C. I. R., Cörvers, F., Traag, T., \& van der Velden, R. K. W. (2012). How do education, cognitive skills, cultural and social capital account for intergenerational earnings persistence? Evidence from the Netherlands. Researchcentrum voor Onderwijs en Arbeidsmarkt, Faculteit der Economische Wetenschappen. ROA Research Memoranda No. 7 https://doi.org/10.26481/umaror.2012007

Document status and date:

Published: 01/01/2012

DOI:

10.26481/umaror.2012007

Document Version:

Publisher's PDF, also known as Version of record

Please check the document version of this publication:

- A submitted manuscript is the version of the article upon submission and before peer-review. There can be important differences between the submitted version and the official published version of record.

People interested in the research are advised to contact the author for the final version of the publication, or visit the DOI to the publisher's website.

- The final author version and the galley proof are versions of the publication after peer review.

- The final published version features the final layout of the paper including the volume, issue and page numbers.

Link to publication

\footnotetext{
General rights rights.

- You may freely distribute the URL identifying the publication in the public portal. please follow below link for the End User Agreement:

www.umlib.nl/taverne-license

Take down policy

If you believe that this document breaches copyright please contact us at:

repository@maastrichtuniversity.nl

providing details and we will investigate your claim.
}

Copyright and moral rights for the publications made accessible in the public portal are retained by the authors and/or other copyright owners and it is a condition of accessing publications that users recognise and abide by the legal requirements associated with these

- Users may download and print one copy of any publication from the public portal for the purpose of private study or research.

- You may not further distribute the material or use it for any profit-making activity or commercial gain

If the publication is distributed under the terms of Article $25 \mathrm{fa}$ of the Dutch Copyright Act, indicated by the "Taverne" license above, 
Maastricht University

Research Centre for Education and the Labour Market | ROA

\title{
How do education, cognitive skills, cultural and social capital account for intergenerational earnings persistence? Evidence from the Netherlands
}

Charlotte Büchner

Frank Cörvers

Tanja Traag

Rolf van der Velden

\section{ROA Research Memorandum}

\author{
ROA-RM-2012/7
}

Research Centre for Education and the Labour Market

Maastricht University

P.O. Box 616,6200 MD Maastricht, The Netherlands

$\mathrm{T}+31433883647 \mathrm{~F}+31433884914$

secretary-roa-sbe@maastrichtuniversity.n www.roa.nl 


\title{
How do education, cognitive skills, cultural and social capital account for intergenerational earnings persistence? Evidence from the Netherlands
}

\author{
Charlotte Büchner \\ Frank Cörvers \\ Tanja Traag \\ Rolf van der Velden
}

ROA-RM-2012/7

May 2012

Research Centre for Education and the Labour Market Maastricht University P.O. Box 616, 6200 MD Maastricht, The Netherlands

$\mathrm{T}+31433883647 \mathrm{~F}+31433884914$

secretary-roa-sbe@maastrichtuniversity.nl

www.roa.nl

\footnotetext{
* The ROA Research Memorandum Series was created in order to make research results available for discussion, before those results are submitted for publication in journals.
} 


\section{Abstract \\ How do education, cognitive skills, cultural and social capital account for intergenerational earnings persistence? Evidence from the Netherlands**}

This study analyzes four different transmission mechanisms, through which father's earnings affect son's earnings: the educational attainment, cognitive skills, the cultural capital of the family and the social capital in the neighborhood. Using a unique data set that combines panel data from a birth cohort with earnings data from a large nationwide income survey and national tax files, our findings show that cognitive skills and schooling of the son account for $50 \%$ of the father-son earnings elasticity. Education by far accounts for the largest part, while cognitive skills mainly work indirectly through educational attainment. Social capital of the neighborhood and cultural capital of the parents account for an additional $6 \%$ of the intergeneration income persistence. From these two additional mechanisms, social capital appears to play a stronger role than the cultural capital of the parents. This means that $44 \%$ of the intergenerational persistence is due to other unobserved characteristics for example personality traits or spillover effects of family assets.

JEL classification: 124, J24, J62

Keywords: education, cognitive skills, cultural capital, social capital, intergenerational mobility

Charlotte Büchner

ROA

Maastricht University

P.O. Box 616

NL-6200 MD Maastricht

The Netherlands

c.buchner@maastrichtuniversity.nl

Tanja Traag

CBS

P.O. Box 4481

6401 CZ Heerlen

The Netherlands

t.traag@cbs.nl
Frank Cörvers

ROA

Maastricht University

P.O. Box 616

6200 MD Maastricht

The Netherlands

frank.corvers@maastrichtuniversity.nl

Rolf van der Velden

ROA

Maastricht University

P.O. Box 616

6200 MD Maastricht

The Netherlands

r.vandervelden@maastrichtuniversity.nl

\footnotetext{
** We would like to thank Marion van den Brakel-Hofmans and Linda Moonen from Statistics Netherlands, who provided us with the data. Furthermore, we would like to thank the members of the advisory committee (Emiel Afman, Nicole Bosch, Sjef Ederveen, Dirk Scheele, Anne van Putten, Jean Marie Wildeboer Schut) as well as Eric Bonsang, Bart Golsteyn, Olivier Marie, Jan Sauermann and Maria Zumbühl from Maastricht University and the participants of the ESPE conference 2011 for their helpful comments.
} 


\section{Introduction}

Intergenerational income mobility is defined as the child's possibility to move up (or down) the income scale relative to one's parents (OECD, 2010). This is usually estimated as the elasticity between father's earnings and son's earnings. Most of this intergenerational income mobility is assumed to be transmitted through the effects of father's earnings on the son's educational attainment, which in turn affects son's own earnings. Other transmission mechanisms may involve cognitive and non-cognitive skills, being transmitted from one generation to the next. The unequal distributions of biological and social endowments as well as the unequal financial possibilities of families to invest in children's educational and labor market career produce unequal opportunities across different social groups. Moreover, countries differ in the extent to which these unequal opportunities are strengthened or weakened. Some education systems are more prone to increase social inequality than others (Shavit \& Blossfeld, 1993; Hanushek \& Woessmann, 2006). As a result we find large differences in the earnings elasticity across countries, ranging from a low 0.15 in Denmark to a high 0.50 for the United Kingdom (Corak, 2006). A recent study by Moonen and Van den Brakel (2011) shows estimates for the Netherlands of 0.22 , which would put the Netherlands in the group of countries of relative high mobility, just between Canada (0.19) and Sweden (0.27) (cf. Corak, 2006). ${ }^{1}$

The main aim of this study is to look at the relative importance of transmission mechanisms that are directly or indirectly related to the association between father's and son's earnings. This strand is less often followed in the economic literature. ${ }^{2}$ Sociological studies are more often interested in these transmission mechanisms, but focus on the intergenerational mobility of socio-economic status rather than on earnings. We attempt to combine both strands of research. We apply the conditional earnings mobility-approach suggested by Blanden, Gregg, and Macmillan (2007) and include - besides education and cognitive skills - measures of cultural and social capital of the son to estimate to what extent these transmission mechanisms account

\footnotetext{
${ }^{1}$ Earlier estimates for the Netherlands can be found in Cörvers (2000a, 2000b, 2004) and Van den Brakel and Moonen (2009).

${ }^{2}$ Most studies in economic literature concentrate on measurement problems in estimating earnings elasticities, for instance, trying to reduce life-cycle bias and measurement error in estimating lifetime income with current income information (e.g. Jenkins, 1987; Haider and Solon, 2006; Grawe, 2006; Nybom and Stuhler, 2011).
} 
for the overall intergenerational earnings elasticity in the Netherlands. For this, we exploit a unique and rich data set that combines panel data from a birth cohort with earnings data from national tax files and a large nationwide income survey.

From a country-specific perspective, the Netherlands are an interesting case to study as they are seen as a 'knowledge-based society', where education is considered the main factor explaining social and economic outcomes, rather than a 'class society' like the United Kingdom (Kraaykamp, Van Eijck and Ultee, 2010). The low earnings elasticity that is reported by Moonen and Van den Brakel (2011) would support this claim. Nevertheless, it would be interesting to see to what extent transmission mechanisms, such as education or the social status of the neighborhood, play a role in the intergenerational income mobility. ${ }^{3}$ As in the study of Blanden et al. (2007) for the United Kingdom, we will decompose the intergenerational earnings elasticity for the Netherlands into several mediating factors that may account for the transmission of earnings between fathers and sons. Similar to the UK study we consider son's cognitive skills (measured by a math and a language performance test and an IQ test at age 12) and educational attainment (measured by years of schooling, field of study and whether or not classes have been repeated during primary education) as transmission mechanisms. Furthermore, we include in our analysis measures for cultural capital of the parents (measured by the number of books parents read and whether or not they regularly visit museums, concerts or theatre plays) and social capital of the neighborhood (measured by the socio-economic composition of the neighborhood in which the sons grew up). Ioannides and Datcher Loury (2004) have extensively discussed the relevance of neighborhood effects for climbing up the social and income ladder. Both the transmission mechanism of cultural capital and social capital are new in the intergenerational income mobility literature. As an additional test of our model, we replace son's earnings with son's house property value, considering this variable as a proxy for son's permanent life income.

Our findings show that cognitive skills and schooling of the son account for about $50 \%$ of the association between father's and son's earnings. By including cultural capital of the parents and social capital of the neighborhood, the explained part increases with $6 \%$. That is, all our mechanisms together account for $56 \%$ of the intergenerational earnings persistence. This means

\footnotetext{
${ }^{3}$ Grawe (2008) points out that families with higher earnings, and especially with higher wealth stocks, are better able to finance education and occupation start-up costs (e.g. for self-employment) of their children which, in turn, reinforces the financial advantages across generations.
} 
that $44 \%$ of the intergenerational earnings persistence is related to other, unobserved factors. Regarding the contribution of each transmission mechanism specifically, education accounts for the largest part, while cognitive skills mainly work indirectly through educational attainment. This is followed by the effect of social capital, which appears to play a bigger role than the cultural capital of the parents in explaining intergenerational earnings persistence.

The next section introduces the modeling approach and decomposition procedure that is adapted from Blanden et al. (2007). The third section describes the data and how the sample is defined for the empirical analysis. Section four presents the results, with regard to the earnings elasticity estimate and the mechanisms that account for intergenerational persistence. Section five summarizes and section six discusses the findings with regard to future research.

\section{Modeling approach and estimation procedure}

Due to the lower labor market participation rate of women, especially in the older cohorts, most of the literature on intergenerational mobility concentrates on the earnings of fathers and sons. ${ }^{4}$ Comparable to other studies, we estimate intergenerational mobility by regressing the logarithm of son's earnings on the logarithm of father's earnings:

$\ln Y_{i}^{\text {son }}=\alpha_{0}+\beta_{1} \ln Y_{i}^{\text {father }}+\varepsilon_{i}$

The $i$ indicates the family to which father and son belong, $\beta_{1}$ is the elasticity ${ }^{5}$ of son's log earnings, $\ln Y_{i}^{\text {son }}$, with regard to the father's $\log$ earnings, $\ln Y_{i}^{\text {father }}$, while $\varepsilon_{i}$ is an idiosyncratic error term.

An issue we have to consider is the transitory fluctuation due to measuring income of fathers and sons at different ages. Following Solon (1992) and Corak and Heisz (1999), we correct for lifecycle differences by including age and age squared for fathers ${ }^{6}$ :

\footnotetext{
${ }^{4}$ For estimates on the father-daughter relationship, see Moonen and Van den Brakel (2011).

${ }^{5}$ Empirical studies in rich countries have always found $\beta$ to lie between zero and one. A value of one would indicate complete intergenerational persistence of incomes, a value of zero complete intergenerational mobility (Corak, 2006).

${ }^{6}$ For sons this correction makes no sense in our analysis, since they all come from the same birth cohort.
} 
The lifecycle-differences also partly reflect the measurement issue of current versus permanent income. The data allow us to measure income only for a single year, for fathers aged between 38 and 58 and for sons around the age of 31. Measuring mobility on the basis of single-year earnings information makes it likely to underestimate the true beta. ${ }^{7}$ As was outlined by Blanden (2009), age-earnings profiles are steeper for those with higher permanent income. Furthermore, "at young ages current income is low compared to permanent income for those with high permanent income, while at older ages current income is higher compared to permanent income for those with high permanent income” (Blanden, 2009: 5). In fact, permanent income that averages income over several years is therefore to be preferred to current income (Solon, 1992; Corak and Heisz, 1999; Haider and Solon, 2006). ${ }^{8}$ In the case of the father's earnings this is probably less of an issue. As the earnings are gathered around the age of 45 , they give a good approximation for life-time earnings, since labor market careers are quite settled at this age (Grawe, 2003, 2004; Corak, 2006). Having single-year earnings information in the case of the sons is probably more problematic, because of the before-mentioned steeper age-earnings profiles for those with high permanent income. In this study we will therefore carry out an additional test by looking at the house property value of the son as an alternative proxy for his permanent income. This house property value was also measured in 2008, when the sons were about 31 years old. Furthermore, we will compare our earnings elasticity estimate with the one reported by Moonen and Van den Brakel (2011), who used another data set for the Netherlands.

As indicated in the introduction, sociological studies have dealt with the same subject, but focused more on intergenerational status mobility rather than intergenerational income mobility (Blau and Duncan, 1967; Bourdieu, 1973; Boudon, 1974). The classic status attainment model assumes that the primary mechanism underlying this relation is that father's socio-economic

\footnotetext{
${ }^{7}$ An alternative way to measure permanent income of the father is to instrument father's income, usually by taking father's education, occupation or social class as instrumental variables (Björklund and Jäntti, 1997; Dearden, Machin and Reed, 1997). However, it is questionable whether these are good instruments, as they are not only correlated with the endogenous variable (father's earnings), but also directly affect son's earnings (Solon, 1992, 2002; Corak, 2006).

${ }^{8}$ Corak and Heisz (1999) suggest to average father's income at least over a period of five consecutive years to reduce the influence of transitory variations. Mazunder (2005) suggests to average even over more years, since a five-year period is still too short to overcome measurement error and to be truly representative as lifecycle income.
} 
status (SES) affects both the cognitive skills of his offspring (the primary effects of social stratification, see Boudon, 1974) as well as the choices they make in education (the secondary effects of social stratification). Both effects determine the level of educational attainment of the son, and this in turn determines son's own SES. There is also albeit a weaker direct effect from father's SES on son's SES, indicating some direct inheritance as well.

The main transmission mechanisms put forward in the sociological literature to explain the family effects on son's educational and occupational attainment are the different forms of capital available to the family: economic, cultural and social capital. The economic capital is directly linked to father's earnings and reflects the possibilities of the family to invest in their children, for instance, buying books or sending them to good schools. The term cultural capital was introduced by Bourdieu (1973) and refers to the symbols, ideas, tastes and preferences that can be used as resources in social interaction. Typically the cultural capital of middle-class parents endows their children with the linguistic and cultural competences that are needed to be successful in education. The concept of cultural capital has been measured in this study by the number of books the parents read and whether or not they regularly visit museums, concerts or theatre plays. These proxies have been shown to be strong predictors of educational attainment (Georg, 2004).

The concept of social capital was originally developed by Coleman and Hoffer (1987). It refers to a person's relations with the broader community. As shown by Coleman and Hoffer (1987), social capital can have a positive impact on a person's development providing a set of norms, especially in communities with high closure. In our study the social capital of the family is proxied by the socio-economic composition of the neighborhood. ${ }^{9}$ The neighborhood is defined as the postal code area in which the son lived at the age of 15. Postal code areas are neighborhoods within cities or municipalities. The Netherlands count almost 4,000 different postal code areas. The socio-economic composition of each neighborhood is based on a principal component analysis that includes variables on the average income per household in that neighborhood, the share of households with low income, the share of people without a paid job,

\footnotetext{
${ }^{9}$ In many studies on social capital, the marital status of the parents is also often used, indicating that single parents have less social capital than couples. As single parents are often female, this is not a good indicator for the current analyses, as we are specifically interested in the father-son earnings elasticity.
} 
and the share of households who, on average, have a low education. ${ }^{10}$ We assume that the social capital of the neighborhood affects values and norms like academic interest and adherence to school norms. Moreover the social capital of the neighborhood can provide a network for the son that will improve his job market opportunities and thus the earnings potential. ${ }^{11}$

With regard to the methodological setup, we adopt the conditional earnings mobility approach of Blanden et al. (2007) to account for the relative contribution of four different mediating factors in the intergenerational earnings relationship. In our study we assume that son's earnings are a function of his cognitive skills, schooling, his parents' cultural capital and the social capital of the neighbourhood:

$$
\ln Y_{i}^{\text {son }}=\lambda+\pi \operatorname{CognSkills}_{i}^{\text {son }}+\rho E d u c_{i}^{\text {son }}+v \text { CultCap }_{i}^{\text {parents }}+\omega \text { SocCap }_{i}^{\text {neighbourhood }}+u_{i}
$$

where $\operatorname{CognSkills}_{i}^{\text {son }}$ is a vector of several cognitive skills measures, $E d u c_{i}^{\text {son }}$ is a vector for measures of schooling of the son, ${ }^{12}$ while CultCap ${ }_{i}^{\text {parents }}$ and SocCapieighbourhood represent a vector of the parent's cultural capital and a proxy for the social capital of the neigborhood. To account for the role of these characteristics as transmission mechanisms, we estimate them separately as a function of father's earnings:

$$
\begin{aligned}
& \text { CognSkills }_{i}^{\text {son }}=\alpha_{1}+\gamma \ln Y_{i}^{\text {father }}+\varepsilon_{1 i} \\
& \text { Educ son }_{i}^{\text {son }}=\alpha_{2}+\delta \ln Y_{i}^{\text {father }}+\varepsilon_{2 i} \\
& \text { CultCap parents }_{i}^{\text {par }}=\alpha_{3}+\phi \ln Y_{i}^{\text {father }}+\varepsilon_{3 i} \\
& \text { SocCap }_{i}^{\text {neighbourhood }}=\alpha_{5}+\kappa \ln Y_{i}^{\text {father }}+\varepsilon_{5 i}
\end{aligned}
$$

\footnotetext{
${ }^{10}$ The analysis yields a first unrotated component that explains $65 \%$ of the total variance. The factor loadings are: average income per household: 0.88 ; share of households with low income: 0.83 ; share of people without a paid job: 0.71; share of households who, on average, have a low education: 0.78 (Sociaal en Cultureel Planbureau, 1998). The social status score is standardized with mean zero and standard deviation one. The original scores have been reversed, so that a high score is associated with a high social status and a low score is associated with a low social status.

${ }^{11}$ Ioannides and Datcher Loury (2004) claim that wage premiums and wage penalties are associated with finding jobs through personal contacts.

${ }^{12}$ We measure son's cognitive skills by performance tests in mathematics and language and an IQ test at the age of 12. Son's schooling is estimated by years of schooling, the field of study, in which he attained his highest educational degree, and whether or not he did repeat classes during primary education. As pointed out in Heckman, Stixrud, and Urzua (2006), schooling and cognitive skills are highly correlated. That is, the estimates of the effect of cognitive skills on earnings will be larger when we do not control for schooling.
} 
Equations [4] to [7] thus display the univariate relationships between the transmission mechanisms and father's earnings. For the conditional decomposition we multiply the returns to cognitive skills by the relationship between father's earnings and cognitive skills and continue with the same procedure, regarding the returns to other transmission mechanisms and their relationship with father's earnings:

$\beta=\pi \gamma+\rho \delta+v \phi+\omega \eta+\frac{\operatorname{Cov}\left(u_{i}, \ln Y_{i}^{\text {father }}\right)}{\operatorname{Var}\left(\ln Y_{i}^{\text {father }}\right)}$

The earnings elasticity-equation [8] displays $\pi \gamma$ as the conditional contribution of cognitive skills, $\rho \delta$ as the conditional contribution of schooling and $v \varphi$ and $\omega \eta$ as the conditional contributions of cultural capital and social capital, respectively. ${ }^{13}$ Furthermore, a term for unexplained mobility in earnings is included that is not transmitted through these mediating factors.

\section{Data}

The data we use is the so-called Secondary Education Cohort of Students (VOCL 1989) that is matched with income information from Dutch national tax files for the sons and a regional income survey (RIO) for the fathers that is also based on tax files. All data have been provided by Statistics Netherlands. The VOCL cohort is a national representative panel of children who were born in 1977 and entered secondary education for the first time in 1989, when most children were around the age of $12 .{ }^{14}$ The VOCL study contains information about parents' schooling and socio-economic status, children's performance scores in math, language and nonverbal intelligence at age 12, as well as children's study field choices and highest educational level attained. The survey comprises 18,294 individuals, 9,460 of whom are male.

\footnotetext{
13 Similar to Blanden et al. (2007), we first look at the unconditional impact of each specification on intergenerational earnings persistence. We include schooling to cognitive skills and then sequentially cultural capital and social capital to see how the mediating factors may affect each other.

${ }^{14}$ Cohort studies are undertaken by Statistics Netherlands on a regular basis since the mid-70s. Other panel studies refer to cohorts born in 1965, 1970, 1981 and 1987 which start to survey individuals at age 12, respectively. A reliable comparison of intergenerational persistence over time with these cohorts was not possible. The main reason for this is that adequate earnings information for fathers was not available for the older cohorts, while sons were still too young in the younger cohorts, in order to obtain adequate earnings information.
} 
The earnings information for the sons is collected from Dutch national tax files of 2008. After matching the cohort survey with administrative earnings data, we have valid earnings information for 7,718 males, which corresponds to $82 \%$ of the original sample. The earnings reflect the gross annual earnings of sons at the age of 31 . The remaining $18 \%$ is either selfemployed (10\%), receives social benefits (5\%) or has no income in that particular year (3\%). ${ }^{15}$ The earnings information of the father is collected from the 1995 Regional Income Survey (RIO). This is a representative sample of approximately one third of the population aged 15 years and older for which income information based on national tax files has been collected. While the matching with the administrative data of 2008 allows us to keep earnings information for all employed sons, we lose observations for fathers by matching the VOCL cohort data with the 1995 RIO data and through the matching of father-son pairs with valid earnings information. ${ }^{16}$ Again these earnings reflect the annual gross earnings of the father. The earnings selection criteria are the same for fathers and sons: individuals need to have positive earnings information and had to work as employee or civil servant for at least 51 weeks in the year when earnings are observed. Further selection was made with regard to father's age, ranging from 38 to $58 .{ }^{17}$ Conditional on these selection criteria we have 2,377 father-son pairs in our sample.

\section{[Figures 1 and 2 about here]}

Figure 1 illustrates the age-earnings profile of fathers in the selected sample. It shows that earnings rise until the age of 51 and then taper off. Table A1 in the appendix shows the descriptive statistics of the annual gross earnings for both fathers and sons. Regarding our transmission mechanisms variables, Table A2 in the appendix shows that the distributions of the explanatory variables in the selected sample do not vary much from those in the full sample. Exceptions are son's cognitive skills and the social status of the neighborhood, which are on average higher in the selected sample than in the full sample.

\footnotetext{
${ }^{15}$ Social benefits refer mainly to unemployment benefits, social welfare or disability benefits. Respondents with no income are mainly students.

${ }^{16}$ The matching of fathers of the school cohort survey with the RIO data is only possible for approximately one third of the cohort sample population. As not all fathers have obtained earnings from labor in 1995 and not every father responded to the parent's questionnaire in the original survey (this could be either total non-response or a father being absent), the resulting proportion for which we have earnings information is even lower.

${ }^{17}$ The relatively wider age range for fathers, unlike the suggestions of Grawe (2003, 2004) and Corak (2006), was chosen to avoid losing more observations.
} 
Figure 2 displays the relation between son's and father's earnings. As expected, it shows a clear positive relation.

\section{Results}

We start with calculating the general earnings elasticity. Column 1 of Table 1 shows an estimate of 0.23 between fathers and sons.

The partial correlation, which corrects for differences in the variance of log earnings between generations, is not significantly different and close to the magnitude of the former earnings elasticity coefficient. The elasticity coefficient of column 1 replicates the estimate that was found by Moonen and Van den Brakel (2011). They applied the same selection criteria as we did here, using a relatively small sample of the Dutch population for which earnings are collected from national tax files. ${ }^{18}$ We take the fact that our coefficient is the same as theirs as an indicator that our data are representative for the Dutch population.

In column 2 of Table 1 we tested whether outliers affect the elasticity by eliminating the top and bottom one percent of father's and son's earnings. This leaves 2,282 father-son pairs in the sample. The results show that the elasticity increases to 0.24 , which is not significantly different from the estimate in column 1 . For the further analysis, however, we continue with the truncated sample to avoid possible follow-up biases due to outliers.

As indicated earlier, we run an additional test replacing earnings with the son's house property value in 2008. Not all sons own a house; therefore the sample further reduces from 2,282 to 1,413 observations. ${ }^{19}$ We first checked whether the earnings elasticity is affected by this selection. This is not the case; the results in column 3 of Table 1 show that the earnings elasticity is still 0.24 . However, the elasticity between father's earnings and son's house property value is much lower, only 0.09 . This is unexpectedly low, as the house property value is regarded as a

\footnotetext{
${ }^{18}$ Moonen and Van den Brakel (2011) use the Income Panel Study as data base. This is a representative sample that started in 1985 and covers 1.5 percent of the overall Dutch population. In their study they look at fathers and sons of all ages and compare 1985 earnings of fathers with 2008 earnings of sons.

${ }^{19}$ For testing the association between father's log earnings and son's log house property value, and the relative contribution of the transmission mechanisms we select the sample to those sons who have positive information both on earnings and on house property. As a robustness check we run the model with the reduced sample also on son's log earnings.
} 
proxy for lifetime income. We have to take into account, however, that the decade in which these sons have bought their houses, the period 1999-2008, is characterized by an extreme increase in the housing prices. The average price of houses sold in that period rose from $€ 145,000$ to $€ 255,000$, which is an increase of $75 \%$. Most of this increase occurred in the beginning of that period. The average earnings in that same period increased with $36 \%$, from $€ 21,600$ to $€ 29,400 .^{20}$ This has important consequences for the son's house property value as measured in 2008. Sons who bought their house relatively early, have profited much more from the rise in the housing prices than sons who bought their house relatively late in that decade. ${ }^{21}$ As a result, the association between father's earnings and son's house property value is strongly decreased. Nevertheless, we will check whether the contribution of the different transmission mechanisms is more or less the same as for the earnings elasticity.

\section{[Table 1 about here]}

\section{Accounting for intergenerational earnings persistence}

The next step deals with the decomposition procedure, as described in section 2. Column 0 of Table 2 displays the relationship between each transmission mechanism and father's earnings. In each regression controls are included for father's age and father's age squared. All mediating variables are strongly related with father's earnings and in the expected direction. Columns 1 to 6 report the sequential earnings regressions of the relationship between the chosen mediating factors and son's earnings. ${ }^{22}$ The explanatory power of the cognitive skills variables in column 1 is almost 0.11 , while column 2 reports a higher R-squared of 0.15 for the schooling variables. Including both specifications in column 3 increases the R-squared only barely up to 0.17 . The

\footnotetext{
${ }^{20}$ The estimates of the development of house prices and earnings are from Statistics Netherlands (www.statline.cbs.nl).

${ }^{21}$ Those, who bought their house relatively early would typically be the lower educated sons who stopped studying at age 18-20, while those, who bought relatively late would typically be the higher educated who graduated at age 23-27.

${ }^{22}$ To keep a maximum number of obeservations in these regressions, we replaced the missing values of some explanatory variables by the population mean and included dummies to indicate if there was a missing value. The variables where missing values were replaced are: math score, language score, IQ score, and number of books parents read. Running regressions which includes only non-missing values does not lead to significant changes in the magnitude of the regression coefficients.
} 
magnitude of the cognitive skills and schooling coefficients is reduced in column 3, which suggests that they are correlated with each other in affecting earnings. With regard to the cognitive skills variables, math skills predict the strongest relationship with son's earnings. Controlled for son's schooling, an increase of one standard deviation in math skills is associated with a $3.7 \%$ increase in earnings. Each year of schooling also increases son's earnings with $3.8 \%$, while not having repeated class during primary education increases earnings with $4.6 \%$. Besides, the chosen study field also affects earnings, with positive effects for engineering, economics and general studies (relative to health studies). The parents' cultural capital (column 4) also has a positive effect on earnings, but this effect disappears as soon as other controls are included (column 6). The social capital of the neighborhood, proxied by the average socioeconomic status (SES) score, has an explanatory power of 0.03 and is positively related with son's earnings (column 5). A one standard deviation increase in the SES score of the neighborhood is associated with a 6.6\% increase in son's earnings. Column 6 includes all predictors, which raises the explanatory power up to 0.18 . As could be expected, including more controls reduces the strength of most of the coefficients. The variables that remain significant in predicting son's earnings are math skills, years of schooling, some study fields (engineering, economics and general studies), not having repeated classes in primary school, as well as the SES score of the neighborhood.

\section{[Table 2 about here]}

The second step of the decomposition procedure is reported in Table 3. Each variable's coefficient from the earnings regressions of columns [1] to [6] in Table 2 is multiplied by the variable's coefficient from the relationship with father's earnings (column [0] in Table 2). As in Blanden et al. (2007: 52), we also summarize these results into different groups: son's cognitive skills, schooling, cultural capital and social capital. The share of intergenerational mobility that is accounted for by the transmission mechanisms is reported as explained components in the lower part of the table. Correlations between the residuals of the son's earnings equation and the relationship with father's earnings are reported as unexplained components. The specification of cognitive skills in column 1 of Table 3 shows that the sum of cognitive skills proxies accounts for about 0.08 points of the 0.24 earnings elasticity coefficient, which is equivalent to $36 \%$. 
Schooling (column 2) accounts for about 0.11 points of the 0.24 earnings elasticity coefficient, that is $45 \%$. Including both specifications together in column 3 increases the explained part that accounts for the total intergenerational persistence up to 50\%. However, schooling still contributes more to this relation (about 0.08 or $34 \%$ ) than cognitive skills ( 0.04 or $16 \%$ ). The decline in the importance of cognitive skills from column 1 to column 3 suggests that cognitive skills primarily affect earnings through their influence on schooling. These findings are similar to the results of the UK study of Blanden et al. (2007). Although the contributions of schooling and cognitive skills are somewhat higher in the Netherlands than in the UK, this suggests certain stability in the extent to which schooling and cognitive skills contribute to intergenerational persistence. ${ }^{23}$ Specifications for cultural capital in column 4 account for only a minor part of the intergenerational earnings persistence. Social capital of the neighborhood on the other hand contributes to intergenerational earnings persistence by about 17\% (0.04 points, column 5). Including all predictors in column 6 increases the overall explained part in accounting for intergenerational persistence to $56 \%$, which is only slightly higher than in column 3 , where only cognitive skills and schooling were considered. In this combined model cognitive skills account for $15 \%$ of the intergenerational persistence, social capital for $9 \%$, while schooling takes up the largest part of 33\% in accounting for the earnings elasticity coefficient $\beta$.

\section{[Table 3 about here]}

As indicated earlier, we performed an additional test using the log house property value of the son in 2008 as a proxy of his permanent income. This has been done on a selected sample for those sons who are house-owner. To check whether this selection in itself affects the intergenerational earnings elasticity and the underlying transmission mechanisms, we repeated the previous analyses for the selected sample. The results are displayed in Tables A4 and A5 in the annex: they show virtually the same outcomes as in Tables 2 and 3. We therefore conclude

\footnotetext{
${ }^{23}$ In their study, Blanden et al. also use non-cognitive skills as transmission mechanisms. They find that cognitive skills account for 0.09 (29\%) of their 0.32 intergenerational earnings elasticity coefficient. When including cognitive, non-cognitive and schooling variables in one model, these account for $46 \%$ of the intergenerational earnings persistence, 31 percent points of which is related to schooling and 8 percent points to cognitive skills (2007: 53f.). It is conceivable that our results converge to theirs, if we would have comparable measures for noncognitive skills.
} 
that the selection on house ownership does not in itself affect the contribution of the different transmission mechanisms.

\section{[Table 4 about here]}

Table 4 presents the results for the analyses using house property value as a proxy for son's permanent income. The results in columns 1 to 6 show that the relation between the transmission mechanisms and the log house property value is in general lower than in the analysis using son's earnings. The R-squared in the full model (column 6) is only 0.06 compared to 0.22 in the model with son's earnings (see Table A4). This is not surprising given the earlier result that the elasticity between father's earnings and son's house property value is also much lower. This clearly affects the estimates for the different parameters. For example, an additional year of schooling is associated with only $1.8 \%$ increase in the log house property value, while the effect on son's earnings is 3.8\% (Table A4). And the coefficient for engineering decreases from 0.133 to 0.013 . The only coefficients that are larger in the analyses with log house property value are repetition of classes during primary school and the SES score of the neighborhood: not repeating classes increases the house property value with some $10 \%$ and coming from a neighborhood in which the average SES score is one standard deviation higher increases the house property value with some $5 \%$.

\section{[Table 5 about here]}

Table 5 reports the results for the decomposition analysis. The overall proportion that is explained in the full model (column 6) is a little bit higher than it was the case for earnings: 62\% instead of 52\% (Table A5). More interesting is the shift in the share of the different transmission mechanisms. The share of cognitive skills has dropped from $11 \%$ to zero, while the share for social capital increased from $8 \%$ to $31 \%$. Cultural capital negatively contributes to explaining the relation between father's earnings and son's house property value. Social capital plays a stronger role in the transmission from father's earnings to son's house property value than in the transmission to son's earnings. It indicates that preferences for a certain material status are 
inherited and can be unrelated to the actual earnings capacity. The choices that people make on the housing market (in terms of what kind of house they will buy) are affected by the kind of neighborhood they grew up in. If they were raised in a neighborhood with a high SES score, the chances increase that they want to live in similar kind of neighborhood again. This is reflected in a strong effect of the SES score of the neighborhood in which they grew up on their current house property value.

\section{Summary}

In this study we examined the intergenerational earnings mobility in the Netherlands and estimated to what extent transmission mechanisms account for intergenerational earnings persistence. Using a combined data set of birth cohort panel data, a large nationwide income survey and register data from tax files, we receive an intergenerational earnings elasticity estimate of 0.23. Compared to other OECD countries, this estimate is in the lower range of intergenerational earnings elasticities, suggesting the Netherlands to be a country of rather high mobility.

We used the decomposition procedure from Blanden et al. (2007), to assess the contribution of different transmission mechanisms that account for this overall elasticity. The results show that cognitive skills and schooling of the son account together for $50 \%$ of the association between father's earnings and son's earnings. Schooling takes up the largest part in this association, while cognitive skills mainly work indirectly by affecting the educational level attained by the son. When including characteristics of the parents' cultural capital and the social capital of the neighborhood, the explained variance of the transmission mechanisms account together for $56 \%$ of the association between father's earnings and son's earnings. However, the reduced relative importance of each specification in the full model indicates that the transmission mechanisms are correlated, which is especially true for the social capital in the neighborhood and son's schooling and cognitive skills.

Replacing son's log earnings with the son's log house property value yields a much lower elasticity coefficient in the association with father's earnings. This is mainly caused by the fact that sons who bought their house in their early twenties profited more from the rise in housing 
prices than sons who bought their house in their early thirties. Since the latter group is more likely to be the higher educated sons, coming from high-earning fathers, this has a depressing effect on the elasticity. The decomposition analysis with house property value shows that this association is mainly transmitted through schooling of the son and the social capital of the neighborhood, while cognitive skills entirely work indirectly through their effect on schooling. The stronger mediating effect of the social capital of the neighborhood indicates that people have a preference to live in the same kind of neighborhood as they grew up in, irrespective of the effect on their earnings.

\section{Discussion}

Although $56 \%$ of the earnings elasticity could be explained by the transmission mechanisms in the model, this still leaves $44 \%$ unexplained. This suggests that other (unobserved) mechanisms may play a role as well, such as the transmission of specific personality traits and attitudes or access to professional networks that are related with income transfers, or more specific, wealth transfers. Studies on family wealth suggest that financial and intellectual family assets 'guarantee' stability in investments in the educational and occupational career of the offspring, among others by the intergenerational transmission of personality traits (e.g. Lindh and Ohlsson, 1996; Blanchflower and Oswald, 1998). In particular, personality traits, such as risk tolerance and entrepreneurial skills, but also spillover effects of family wealth that is related to father's earnings, are likely candidates to account for a part of the intergenerational persistence that as yet has been left unexplained (e.g. Rauch, 1993; Banabou, 1996). Future research should focus more on these other types of transmission mechanisms.

Another issue to be addressed in future research is the problem of measurement error. Although the decomposition model that we used has attractive properties in being very straightforward, a drawback of the model is that results depend, among others, on the extent to which concepts have been well measured. Put simply, if education is measured with more accuracy than the cognitive skills, education will turn out also to explain more of the intergenerational earnings persistence. Other models, such as LISREL, could separate the structural from the measurement model, thus allowing concepts to be measured with different levels of reliability. 
As our goal for this study was to replicate the Blanden et al. analysis, we deliberately followed their decomposition model, despite the above-mentioned drawback. Within this scope, it is interesting to see that our findings are pretty close to those of the UK study with regard to the role of schooling and cognitive skills in accounting for intergenerational earnings persistence.

In the introduction we stated that the Netherlands are a knowledge-based society rather than a class society, in which the country's prosperity and welfare structure is to a large extent attributed to its social, cultural and economic openness. This seems not to comply fully with our findings. The similarity to the UK study in the relative contribution of schooling and cognitive skills rather suggests that a reproduction of intergenerational inequality between high and low income families contains a stable element that is independent from the state structure. It further suggests that policy interventions that aim to improve the socio-economic outcomes of poorer children may partly be ineffective. If any, some of the more promising policy actions in stimulating intergenerational mobility target intragenerational improvements, such as enhancing job opportunities of poorer parents (for example, funding self-employment with substantial startup capital) and children's intellectual and personal formation in early childhood. Such investments are likely to produce revenues in the longer run and establish assets that persist over generations. Further research could be directed towards the impact of intervening in investment strategies of schools, parents and children on upward mobility of children, especially for those from a poorer social background.

\section{References}

Banabou, R. (1996). Equity and Efficiency in Human Capital Investment: The Local Connection. Review of Economic Studies, 63(2): 237-264.

Becker, G. \& Tomes, N. (1979). An Equilibrium Theory of the Distribution of Income and Intergenerational Mobility. The Journal of Political Economy, 87(6): 1153-1189.

Björklund, A. \& Jäntti, M. (1997). Intergenerational Income Mobility in Sweden Compared to the United States. The American Economic Review, 87(5): 1009-1018.

Blanchflower, D.G. \& Oswald, A.J. (1998).What Makes an Entepreneur? Journal of Labor Economics, 16(1): 26-60. 
Blanden, J., Gregg, P. \& Macmillan, L. (2007). Accounting for Intergenerational Income Persistence: Noncognitive Skills, Ability and Education. The Economic Journal, 117: C43-C60.

Blanden, J. (2009). How Much Can We Learn From International Comparisons Of Intergenerational Mobility? CEE Discussion Paper, No. 111.

Blau, P.M. \& Duncan, O.D. (1967). The American Occupational Structure. New York: Wiley.

Boudon, R. (1974). Education, Opportunity and Social Inequality, New York: John, Wiley \& Sons.

Bourdieu, P. (1973). Cultural Reproduction and Social Reproduction. In: Brown, R. (ed.): Knowledge, Education, and Cultural Change: Papers in the Sociology of Education, London: Tavistock: 71-112.

Coleman, J. S. \& Hoffer, T. (1987), Public and Private High Schools: The Impact of Communities. New York: Basic Books.

Corak, M. \& Heisz, A. (1999). The Intergenerational Earnings and Income Mobility of Canadian Men: Evidence from Longitudinal Income Tax Data. Journal of Human Resources, 34: 504-33.

Corak, M. (2006). Do poor children become poor adults? Lessons for public policy from a cross country comparison of generational earnings mobility. Research on Economic Inequality, 13: 143-88.

Cörvers, F. (2000a). Inkomensmobiliteit tussen generaties: laagste inkomensklassen weinig mobiel, Index: feiten en cijfers over onze samenleving, 7(7): 30-31.

Cörvers, F. (2000b). Inkomensmobiliteit tussen huishoudens met lage inkomens van generatie op generatie. Armoedemonitor 2000, SCP/CBS, Den Haag: 93-103.

Cörvers, F. (2004). Income mobility of successive generations. In: SCP/CBS, The poor side of the Netherlands: Results from the Dutch 'Poverty Monitor' 1997-2003, The Hague: 120124.

Dearden, L. Machin, S. and Reed, H. (1997). Intergenerational Mobility in Britain. Economic Journal, 107: 47-64.

Georg, Werner (2004). Cultural Capital and Social Inequality in the Life Course, European Sociological Review, 20,4, 333-344. 
Grawe, N.D. (2003). Life-cycle Bias in the Estimation Bias of Intergenerational Earnings Persistence. Family and Labour Studies, Analytical Studies Branch Research Paper, No. 207. Ottawa: Statistics Canada.

Grawe, N.D. (2004). Intergenerational Mobility for Whom? The Experience of High and Low Earnings Sons in International Perspective. In: Miles Corak (ed), Generational Income Mobility in North America and Europe. Cambridge: Cambridge University Press.

Grawe, N.D. (2006). Lifecycle Bias in Estimates of Intergenerational Earnings Persistence. Labour Economics, 13(5): 551-570.

Grawe, N.D. (2008). "Wealth and Economic Mobility” as part of the Pew-funded Economic Mobility Project. Download: http://www.economicmobility.org/assets/pdfs/EMP_LitReview_Wealth.pdf

Haider, S. \& Solon, G. (2006). Life-cycle Variation in the Association between Current and Lifetime Earnings, The American Economic Review, 96: 1308-1320.

Hanushek, E.A. \& Woessmann, L. (2006). Does Educational Tracking Affect Performance and Inequality? Differences-in-Differences Evidence across Countries, Economic Journal, Vol. 116 (510:C63).

Heckman, J.J., Stixrud, J. \& Urzua, S. (2006). The Effects of Cognitive and Noncognitive Abilities on Labor Market Outcomes and Social Behavior. Journal of Labor Economics, 24(3), 411-482.

Ioannides, Y. M. \& Datcher Loury, L. (2004). Job Information Networks, Neighborhood Effects, and Inequality. Journal of Economic Literature, 42(4): 1056-1093.

Jenkins, S. (1987). Snapshots versus Movies: 'Lifecycle biases' and the Estimation of Intergenerational Earnings Inheritance. European Economic Review, 31(5): 1149-1158.

Kraaykamp, G., Van Eijck, K. \& Ultee, W. (2010). Status, Class and Culture in the Netherlands, in T.W. Chan (eds). Social Status and Cultural Consumption. Cambridge: University Press.

Lindh, T. \& Ohlsson, H. (1996). Self-employment and Windfall Gains: Evidence from the Swedish Lottery. Economic Journal, 106(439): 1515-1526.

Mazumder, B. (2005). Earnings Mobility in the US: A New Look at Intergenerational Mobility. Unpublished, Federal Reserve Bank of Chicago.

Moonen, L. \& Van den Brakel, M. (2011). Measuring Intergenerational Income Mobility, Centraal Bureau voor de Statistiek, Den Haag/Heerlen, www.cbs.nl. 
Nybom, M. \& Stuhler, J. (2011). Heterogeneous Income Profiles and Life-Cycle Bias in Intergenerational Mobility Estimation. IZA Discussion Paper, No. 5697.

OECD (2010). A Family Affair: Intergenerational Social Mobility across OECD Countries. In: OECD, Going for Growth, Chapter 5: 181-198, Paris.

Rauch, J.E. (1993). Productivity Gains from Geographic Concentration on Human Capital: Evidence from the Cities. Journal of Urban Economics, 34(3): 380-400.

Shavit, Y. \& Blossfeld, H.P. (1993). Persistent Inequality: Changing Educational Attainment in Thirteen Countries. Westview Press.

Sociaal en Cultureel Planbureau (1998), Van hoog naar laag; van laag naar hoog: De sociaalruimtelijke ontwikkeling van wijken tussen 1971 en 1995, Den Haag: Sociaal en Cultureel Planbureau

Solon, G. (1992). Intergenerational Income Mobility in the United States. American Economic Review, 82(3): 393-408.

Solon, G. (2002). Cross-Country Differences in Intergenerational Earnings Mobility. Journal of Economic Perspectives, 16(3): 59-66.

Van den Brakel, M. \& Moonen, L. (2009). Is armoede erfelijk? Sociaaleconomische trends, 2e kwartaal 2009, Centraal Bureau voor de Statistiek, Den Haag/Heerlen. 


\section{Figure 1}

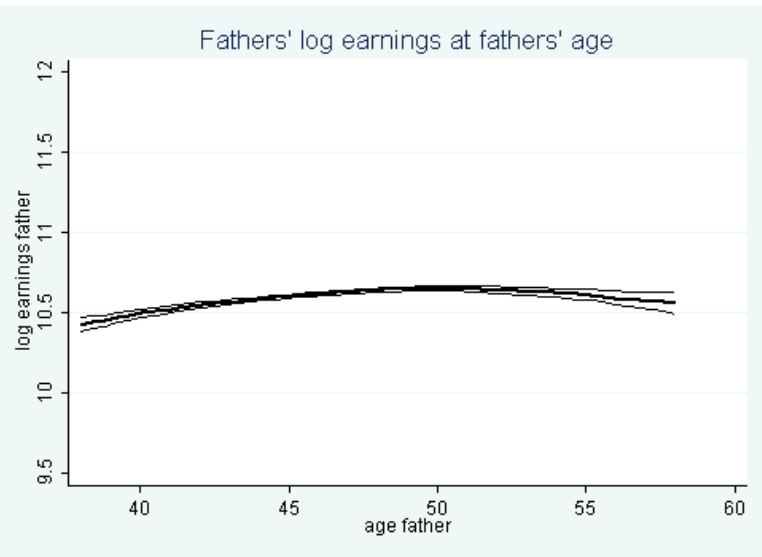

Figure 2

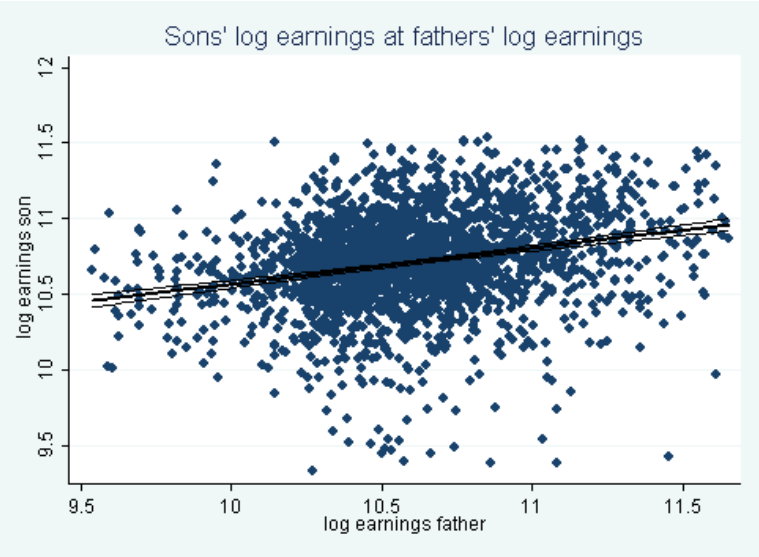

Note: Log earnings of fathers and sons are truncated at the top and bottom 1 percent.

Table 1: Income elasticities

\begin{tabular}{|c|c|c|c|c|c|}
\hline & {$[1]$} & {$[2]$} & [3] & [4] & \\
\hline beta & $0.225 * * * \quad(0.022)$ & $0.238 * * * \quad(0.019)$ & $0.239 * * * \quad(0.020)$ & $0.085 * * *$ & $(0.025)$ \\
\hline partial correlation & $0.228 * * * \quad(0.022)$ & $0.220 * * * \quad(0.017)$ & $0.188 * * * \quad(0.016)$ & $0.074 * * *$ & $(0.021)$ \\
\hline $\mathrm{N}$ & 2377 & 2282 & 1413 & 1413 & \\
\hline
\end{tabular}

Note: $* * * p<0.01$. Robust standard errors in parentheses. Column [1] reports elasticity coefficients for the untruncated earnings sample, column [2] for the truncated earnings sample where the top and bottom 1\% of father's and son's earnings are removed. Column [3] reports the earnings elasticity coefficient for the truncated and selected sample (valid information on son's earnings and son's house property value). Column [4] reports the elasticity coefficient between father's log earnings and son's house property value for the truncated and selected sample (valid information on son's earnings and son's house property value). All regressions are controlled for father's age and father's age squared. 
Table 2: Relationships between transition mechanisms, father's log earnings and son's log earnings

\begin{tabular}{|c|c|c|c|c|c|c|c|c|c|c|c|c|c|c|}
\hline \multirow[b]{2}{*}{ Dependent variable } & \multicolumn{2}{|c|}{$\begin{array}{l}\text { Father's log earnings } \\
{[0]}\end{array}$} & \multicolumn{2}{|l|}{ [1] } & \multicolumn{2}{|l|}{ [2] } & \multirow{2}{*}{$\begin{array}{l}{[3]} \\
\text { coeff }\end{array}$} & \multicolumn{3}{|c|}{$\begin{array}{c}\text { Son's log earnings } \\
{[4]}\end{array}$} & \multicolumn{2}{|l|}{$[5]$} & \multicolumn{2}{|l|}{ [6] } \\
\hline & coeff & SE & coeff & SE & coeff & $\mathrm{SE}$ & & SE & coeff & SE & coeff & $\mathrm{SE}$ & coeff & SE \\
\hline Math performance & $0.759 * * *$ & $(0.055)$ & $0.075^{* * *}$ & $(0.008)$ & & & $0.037 * * *$ & $(0.009)$ & & & & & $0.035 * * *$ & $(0.009)$ \\
\hline Language performance & $0.783 * * *$ & $(0.056)$ & $0.031 * * *$ & $(0.009)$ & & & 0.010 & $(0.009)$ & & & & & 0.008 & $(0.009)$ \\
\hline IQ test & $0.312 * * *$ & $(0.058)$ & $0.011^{*}$ & $(0.006)$ & & & 0.007 & $(0.006)$ & & & & & 0.007 & $(0.006)$ \\
\hline Years of schooling & $2.408^{* * *}$ & $(0.136)$ & & & $0.049 * * *$ & $(0.003)$ & $0.038 * * *$ & $(0.003)$ & & & & & $0.037 * * *$ & $(0.003)$ \\
\hline Field of study (Ref. health) & & & & & & & & & & & & & & \\
\hline General & $0.046 * *$ & $(0.018)$ & & & $0.171^{* * *}$ & $(0.036)$ & $0.129 * * *$ & $(0.036)$ & & & & & $0.126^{* * *}$ & $(0.036)$ \\
\hline Engineering & $-0.217 * * *$ & $(0.029)$ & & & $0.140 * * *$ & $(0.027)$ & $0.126 * * *$ & $(0.027)$ & & & & & $0.124 * * *$ & $(0.027)$ \\
\hline Economics & $0.040 *$ & $(0.022)$ & & & $0.134 * * *$ & $(0.029)$ & $0.122 * * *$ & $(0.029)$ & & & & & $0.120 * * *$ & $(0.029)$ \\
\hline Agriculture and other & $0.041^{* * *}$ & $(0.012)$ & & & 0.026 & $(0.039)$ & 0.016 & $(0.039)$ & & & & & 0.014 & $(0.039)$ \\
\hline Social science and law & $0.060 * * *$ & $(0.011)$ & & & 0.034 & $(0.038)$ & 0.026 & $(0.038)$ & & & & & 0.025 & $(0.038)$ \\
\hline $\begin{array}{l}\text { Son did not repeat classes in } \\
\text { primary school }\end{array}$ & $0.062 * * *$ & $(0.015)$ & & & $0.063 * *$ & $(0.023)$ & $0.046^{* *}$ & $(0.023)$ & & & & & $0.047^{* *}$ & $(0.023)$ \\
\hline Number of books parents read & $0.739 * * *$ & $(0.071)$ & & & & & & & $0.007 * *$ & $(0.004)$ & & & 0.000 & $(0.003)$ \\
\hline regularly & $0.303^{* * *}$ & $(0.018)$ & & & & & & & $0.046^{* * *}$ & $(0.015)$ & & & -0.008 & $(0.014)$ \\
\hline SES score neighborhood & $0.626^{* * *}$ & $(0.033)$ & & & & & & & & & $0.066^{* * *}$ & $(0.008)$ & $0.036 * * *$ & $(0.008)$ \\
\hline R-squared & & & 0.105 & & 0.154 & & 0.168 & & 0.007 & & 0.028 & & 0.177 & \\
\hline $\mathrm{N}$ & & & 2238 & & 2238 & & 2238 & & 2238 & & 2238 & & 2238 & \\
\hline
\end{tabular}


Table 3: Accounting for the relationship between father's earnings and son's earnings

\begin{tabular}{|c|c|c|c|c|c|c|}
\hline & [1] & {$[2]$} & [3] & [4] & [5] & [6] \\
\hline Math performance & 0.0569 & & 0.0281 & & & 0.0266 \\
\hline Language performance & 0.0243 & & 0.0078 & & & 0.0063 \\
\hline IQ test & 0.0034 & & 0.0022 & & & 0.0022 \\
\hline Sum of cognitive skills & 0.0846 & & 0.0381 & & & 0.0351 \\
\hline Years of schooling & & 0.1180 & 0.0915 & & & 0.0891 \\
\hline \multicolumn{7}{|l|}{ Field of study (Ref. health) } \\
\hline General & & 0.0079 & 0.0059 & & & 0.0058 \\
\hline Engineering & & -0.0303 & -0.0273 & & & -0.0269 \\
\hline Economics & & 0.0054 & 0.0049 & & & 0.0048 \\
\hline Agriculture and other & & 0.0011 & 0.0007 & & & 0.0006 \\
\hline Social science and law & & 0.0020 & 0.0016 & & & 0.0015 \\
\hline Son did not repeat classes in primary school & & 0.0039 & 0.0029 & & & 0.0029 \\
\hline Sum of schooling & & 0.1080 & 0.0802 & & & 0.0778 \\
\hline Number of books parents read & & & & 0.0052 & & 0.0000 \\
\hline Parents visit concert/museum regularly & & & & 0.0139 & & -0.0024 \\
\hline Sum of cultural capital & & & & 0.0191 & & -0.0024 \\
\hline SES score neighborhood & & & & & 0.0413 & 0.0225 \\
\hline Sum of social capital & & & & & 0.0413 & 0.0225 \\
\hline Explained & $\mathbf{0 . 0 8 4 6}(36 \%)$ & $\mathbf{0 . 1 0 8 0}(45 \%)$ & $\mathbf{0 . 1 1 8 3}(50 \%)$ & $\mathbf{0 . 0 1 9 1}(8 \%)$ & $0.0413(17 \%)$ & $0.1330(56 \%)$ \\
\hline Unexplained & 0.1536 & 0.1302 & 0.1199 & 0.2191 & 0.1969 & 0.1052 \\
\hline Total & 0.2382 & 0.2382 & 0.2382 & 0.2382 & 0.2382 & 0.2382 \\
\hline
\end{tabular}

Note: The columns provide the decomposition derived from the earnings relationships in Table 2. We decompose the overall earnings persistence into the contribution of each factor by multiplying each variable's coefficient in the earnings equation by its relationship with father's earnings (coefficient of column [0] multiplied with the coefficient of column [1]-[6] in Table 2). 
Table 4: Relationships between transition mechanisms, father's log earnings and son's log house property value (selected sample)

\begin{tabular}{|c|c|c|c|c|c|c|c|c|c|c|c|c|c|c|}
\hline \multirow[b]{3}{*}{ Dependent variable } & \multirow{3}{*}{\multicolumn{2}{|c|}{$\begin{array}{l}\text { Father's log } \\
\text { earnings } \\
0]\end{array}$}} & \multicolumn{12}{|c|}{ Son's log house property value } \\
\hline & & & {$[1]$} & & {$[2]$} & & [3] & & {$[4]$} & & [5] & & [6] & \\
\hline & coeff & & coeff & SE & coeff & SE & coeff & SE & coeff & SE & coeff & SE & coeff & SE \\
\hline Math performance & $0.709 * * *$ & $(0.071)$ & $0.040 * * *$ & $(0.011)$ & & & $0.021 *$ & $(0.012)$ & & & & & 0.018 & $(0.012)$ \\
\hline Language performance & $0.813^{* * *}$ & $(0.073)$ & 0.001 & $(0.011)$ & & & -0.010 & $(0.011)$ & & & & & -0.014 & $(0.011)$ \\
\hline IQ test & $0.309 * * *$ & $(0.080)$ & 0.001 & $(0.008)$ & & & -0.003 & $(0.008)$ & & & & & -0.004 & $(0.006)$ \\
\hline Years of schooling & $2.286 * * *$ & $(0.186)$ & & & $0.019 * * *$ & $(0.003)$ & $0.017 * * *$ & $(0.004)$ & & & & & $0.018 * * *$ & $(0.004)$ \\
\hline Field of study (Ref. health) & & & & & & & & & & & & & & \\
\hline General & 0.039 & $(0.024)$ & & & $0.076^{* *}$ & $(0.037)$ & $0.072 *$ & $(0.038)$ & & & & & $0.070^{*}$ & $(0.037)$ \\
\hline Engineering & $-0.269 * * *$ & $(0.041)$ & & & 0.025 & $(0.030)$ & 0.021 & $(0.030)$ & & & & & 0.013 & $(0.030)$ \\
\hline Economics & $0.088 * *$ & $(0.032)$ & & & -0.015 & $(0.033)$ & -0.017 & $(0.033)$ & & & & & -0.025 & $(0.032)$ \\
\hline Agriculture and other & 0.022 & $(0.017)$ & & & 0.018 & $(0.051)$ & 0.016 & $(0.051)$ & & & & & 0.012 & $(0.051)$ \\
\hline Social science and law & $0.077 * * *$ & $(0.015)$ & & & -0.014 & $(0.046)$ & -0.013 & $(0.046)$ & & & & & -0.025 & $(0.046)$ \\
\hline $\begin{array}{l}\text { Son did not repeat classes in } \\
\text { primary school }\end{array}$ & 0.026 & $(0.019)$ & & & $0.111^{* *}$ & $(0.039)$ & $0.108 * *$ & $(0.039)$ & & & & & $0.106^{* *}$ & $(0.038)$ \\
\hline Number of books parents read & $0.810^{* * *}$ & $(0.122)$ & & & & & & & -0.005 & $(0.005)$ & & & $-0.009 *$ & $(0.005)$ \\
\hline regularly & $0.270^{* * *}$ & $(0.036)$ & & & & & & & 0.004 & $(0.017)$ & & & -0.023 & $(0.018)$ \\
\hline SES score neighborhood & $0.548^{* * *}$ & $(0.063)$ & & & & & & & & & $0.056 * * *$ & $(0.009)$ & $0.049 * * *$ & $(0.010)$ \\
\hline R-squared & & & 0.022 & & 0.035 & & 0.042 & & 0.002 & & 0.023 & & 0.063 & \\
\hline $\mathrm{N}$ & & & 1386 & & 1386 & & 1386 & & 1386 & & 1386 & & 1386 & \\
\hline
\end{tabular}


Table 5: Accounting for the relationship between father's log earnings and son's log house property value

\begin{tabular}{|c|c|c|c|c|c|c|}
\hline & [1] & [2] & [3] & [4] & [5] & [6] \\
\hline Math performance & 0.0284 & & 0.0149 & & & 0.0128 \\
\hline Language performance & 0.0008 & & -0.0081 & & & -0.0114 \\
\hline IQ test & 0.0003 & & -0.0009 & & & -0.0012 \\
\hline Sum of cognitive skills & 0.0295 & & 0.0059 & & & 0.0002 \\
\hline Years of schooling & & 0.0434 & 0.0389 & & & 0.0411 \\
\hline Field of study (Ref. health) & & & & & & \\
\hline General & & 0.0030 & 0.0028 & & & 0.0027 \\
\hline Engineering & & -0.0067 & -0.0056 & & & -0.0035 \\
\hline Economics & & -0.0013 & -0.0015 & & & -0.0022 \\
\hline Agriculture and other & & 0.0004 & 0.0004 & & & 0.0003 \\
\hline Social science and law & & -0.0011 & -0.0010 & & & -0.0019 \\
\hline Son did not repeat classes in primary school & & 0.0029 & 0.0028 & & & 0.0028 \\
\hline Sum of schooling & & 0.0406 & 0.0368 & & & 0.0393 \\
\hline Number of books parents read & & & & -0.0041 & & -0.0073 \\
\hline Parents visit concert/museum regularly & & & & 0.0011 & & -0.0062 \\
\hline Sum of cultural capital & & & & -0.0030 & & -0.0135 \\
\hline SES score neighborhood & & & & & 0.0307 & 0.0269 \\
\hline Sum of social capital & & & & & 0.0307 & 0.0269 \\
\hline Explained & $0.0295(34 \%)$ & $\mathbf{0 . 0 4 0 6}(47 \%)$ & $0.0427(50 \%)$ & $-0.0030(-4 \%)$ & $0.0307(36 \%)$ & $0.0529(62 \%)$ \\
\hline Unexplained & 0.0559 & 0.0448 & 0.0427 & 0.0884 & 0.0547 & 0.0325 \\
\hline Total & 0.0854 & 0.0854 & 0.0854 & 0.0854 & 0.0854 & 0.0854 \\
\hline
\end{tabular}

each variable's coefficient in the equation by its relationship with father's earnings (coefficient of column [0] in Table 4) multiplied with the coefficient of column [1]-[6] in Table 


\section{Appendix}

Table A1: Descriptive statistics on father's and son's earnings

\begin{tabular}{|c|c|c|c|c|c|c|c|c|c|}
\hline & Mean & SD & Min & Max & $\begin{array}{l}\text { 1st } \\
\text { pctile }\end{array}$ & $\begin{array}{l}\text { 25th } \\
\text { pctile }\end{array}$ & median & $\begin{array}{l}75 \text { th } \\
\text { pctile }\end{array}$ & $\begin{array}{l}\text { 99th } \\
\text { pctile }\end{array}$ \\
\hline Father's earnings in 1995 (Euro) & 43181 & 16355 & 13899 & 114886 & 16955 & 32248 & 39346 & 49587 & 101994 \\
\hline Log father's earnings in 1995 (Euro) & 10.610 & 0.349 & 9.540 & 11.652 & 9.738 & 10.381 & 10.580 & 10.811 & 11.533 \\
\hline Son's earnings in 2008 (Euro) & 47087 & 14729 & 11221 & 101706 & 16905 & 37156 & 44967 & 54951 & 90366 \\
\hline Log son's earnings in 2008 (Euro) & 10.710 & 0.322 & 9.326 & 11.530 & 9.735 & 10.523 & 10.714 & 10.914 & 11.412 \\
\hline
\end{tabular}

Note: Father's earnings are calculated in 2008 earnings, deflated by consumer price index. Earnings of fathers and sons are truncated at the top and bottom 1 percent.

Table A2: Descriptive statistics for the full and selected sample

\begin{tabular}{|c|c|c|c|c|c|c|}
\hline & \multicolumn{2}{|c|}{ Full sample } & \multicolumn{4}{|c|}{ Selected sample } \\
\hline & Mean & SD & Mean & SD & Min & Max \\
\hline \multicolumn{7}{|l|}{ Surveyed via son } \\
\hline \multicolumn{7}{|l|}{ Cognitive skills at age 12} \\
\hline Math score & 0.195 & $(1.06)$ & 0.251 & $(1.04)$ & -2.03 & 2.07 \\
\hline Language score & -0.150 & $(1.07)$ & -0.085 & $(1.03)$ & -2.96 & 2.20 \\
\hline IQ test score & -0.175 & $(1.05)$ & -0.126 & $(1.04)$ & -3.79 & 3.41 \\
\hline Years of schooling & 13.26 & $(3.35)$ & 13.65 & $(3.28)$ & 6 & 19 \\
\hline Did not repeat classes in primary school & 0.92 & $(0.28)$ & 0.93 & $(0.25)$ & 0 & 1 \\
\hline General studies & 0.14 & $(0.34)$ & 0.09 & $(0.29)$ & 0 & 1 \\
\hline Engineering studies & 0.46 & $(0.50)$ & 0.49 & $(0.50)$ & 0 & 1 \\
\hline Economics studies & 0.23 & $(0.42)$ & 0.23 & $(0.42)$ & 0 & 1 \\
\hline Agriculture and other studies & 0.06 & $(0.24)$ & 0.05 & $(0.22)$ & 0 & 1 \\
\hline Social sciences and law studies & 0.05 & $(0.23)$ & 0.06 & $(0.25)$ & 0 & 1 \\
\hline \multicolumn{7}{|l|}{ Surveyed via parents } \\
\hline \multicolumn{7}{|l|}{ Cultural capital at age 12} \\
\hline Number of books read by parents & 1.54 & $(1.96)$ & 1.60 & $(1.81)$ & 0 & 44 \\
\hline
\end{tabular}




\begin{tabular}{|c|c|c|c|c|c|c|}
\hline Parents visit concert/museum/theatre regularly & 0.55 & $(0.50)$ & 0.57 & $(0.49)$ & 0 & 1 \\
\hline \multicolumn{7}{|l|}{ Social capital at age 15} \\
\hline Social status of the neighborhood & -0.057 & $(0.94)$ & 0.029 & $(0.83)$ & -3.751 & 3.354 \\
\hline \multicolumn{7}{|l|}{ Proxy for son's permanent income } \\
\hline Log house property value son & 12.25 & $(0.34)$ & 12.23 & $(0.31)$ & 9.95 & 14.45 \\
\hline
\end{tabular}

Table A3: Pairwise correlations of selected variables

\begin{tabular}{|c|c|c|c|c|c|c|c|c|c|c|c|}
\hline & $\begin{array}{l}\text { Log } \\
\text { earnings } \\
\text { father }\end{array}$ & $\begin{array}{l}\text { Log } \\
\text { earnings } \\
\text { son }\end{array}$ & $\begin{array}{l}\text { Math } \\
\text { skills } \\
\text { son } \\
\end{array}$ & $\begin{array}{l}\text { Languag } \\
\text { e skills } \\
\text { son } \\
\end{array}$ & $\begin{array}{l}\text { IQ test } \\
\text { son }\end{array}$ & $\begin{array}{l}\text { Years of } \\
\text { schooling } \\
\text { son }\end{array}$ & $\begin{array}{l}\text { Son did } \\
\text { not } \\
\text { repeat } \\
\text { classes }\end{array}$ & $\begin{array}{l}\text { Number } \\
\text { of books } \\
\text { parents } \\
\text { read }\end{array}$ & $\begin{array}{l}\text { Parents } \\
\text { visit } \\
\text { concerts/ } \\
\text { museums }\end{array}$ & $\begin{array}{l}\text { Social } \\
\text { status } \\
\text { neigh- } \\
\text { borhood }\end{array}$ & $\begin{array}{l}\text { Log } \\
\text { house } \\
\text { property } \\
\text { value son }\end{array}$ \\
\hline Log earnings father & 1.000 & & & & & & & & & & \\
\hline Log earnings son & $0.254^{*}$ & 1.000 & & & & & & & & & \\
\hline Math skills son & $0.271^{*}$ & $0.315^{*}$ & 1.000 & & & & & & & & \\
\hline Language skills son & $0.267^{*}$ & $0.268^{*}$ & $0.665^{*}$ & 1.000 & & & & & & & \\
\hline IQ test son & $0.128 *$ & $0.128 *$ & $0.289 *$ & $0.235^{*}$ & 1.000 & & & & & & \\
\hline Years of schooling son & $0.316^{*}$ & $0.359 *$ & $0.569 *$ & $0.538 *$ & $0.201^{*}$ & 1.000 & & & & & \\
\hline Son did not repeat classes & $0.077^{*}$ & $0.129 *$ & $0.224 *$ & $0.184 *$ & $0.076^{*}$ & $0.216^{*}$ & 1.000 & & & & \\
\hline $\begin{array}{l}\text { Number of books parents } \\
\text { read }\end{array}$ & $0.160^{*}$ & $0.054 *$ & $0.101^{*}$ & $0.108^{*}$ & $0.082 *$ & $0.131 *$ & 0.029 & 1.000 & & & \\
\hline $\begin{array}{l}\text { Parents visit } \\
\text { concerts/museums }\end{array}$ & $0.205^{*}$ & $0.067 *$ & $0.172 *$ & $0.168 *$ & 0.022 & $0.213^{*}$ & $0.055^{*}$ & $0.183^{*}$ & 1.000 & & \\
\hline Social status neighborhood & $0.273^{*}$ & $0.167 *$ & $0.213^{*}$ & $0.196 *$ & $0.076^{*}$ & $0.175^{*}$ & $0.062 *$ & $0.073 *$ & $0.120^{*}$ & 1.000 & \\
\hline $\begin{array}{l}\text { Log house property value } \\
\text { son }\end{array}$ & $0.104^{*}$ & $0.296 *$ & $0.134 *$ & $0.096 *$ & $0.042 *$ & $0.149 *$ & $0.105^{*}$ & -0.030 & -0.009 & $0.151^{*}$ & 1.000 \\
\hline
\end{tabular}


Table A4: Relationships between transition mechanisms, father's log earnings and son's log earnings (selected sample)

\begin{tabular}{|c|c|c|c|c|c|c|c|c|c|c|c|c|c|c|}
\hline Dependent variable & $\begin{array}{l}\text { Father's log } \\
{[0]} \\
\text { coeff }\end{array}$ & $\begin{array}{l}\text { earnings } \\
\text { SE }\end{array}$ & $\begin{array}{l}{[1]} \\
\text { coeff }\end{array}$ & $\mathrm{SE}$ & $\begin{array}{l}{[2]} \\
\text { coeff }\end{array}$ & SE & $\begin{array}{l}{[3]} \\
\text { coeff }\end{array}$ & $\begin{array}{l}\text { Son's log } \\
\text { SE }\end{array}$ & $\begin{array}{l}\text { arnings } \\
\text { [4] } \\
\text { coeff }\end{array}$ & SE & $\begin{array}{l}{[5]} \\
\text { coeff }\end{array}$ & SE & $\begin{array}{l}{[6]} \\
\text { coeff }\end{array}$ & SE \\
\hline Math performance & $0.709 * * *$ & $(0.071)$ & $0.063 * * *$ & $(0.009)$ & & & $0.023 * *$ & $(0.010)$ & & & & & $0.021 * *$ & $(0.010)$ \\
\hline Language performance & $0.813^{* * *}$ & $(0.073)$ & $0.037 * * *$ & $(0.009)$ & & & 0.014 & $(0.009)$ & & & & & 0.010 & $(0.009)$ \\
\hline IQ test & $0.309 * * *$ & $(0.080)$ & $0.016^{* *}$ & $(0.007)$ & & & $0.012^{*}$ & $(0.006)$ & & & & & $0.012^{*}$ & $(0.006)$ \\
\hline Years of schooling & $2.286 * * *$ & $(0.186)$ & & & $0.047 * * *$ & $(0.003)$ & $0.038 * * *$ & $(0.003)$ & & & & & $0.038 * * *$ & $(0.003)$ \\
\hline Field of study (Ref. health) & & & & & & & & & & & & & & \\
\hline General & 0.039 & $(0.024)$ & & & $0.164^{* * *}$ & $(0.039)$ & $0.135^{* * *}$ & $(0.039)$ & & & & & $0.134^{* * *}$ & $(0.038)$ \\
\hline Engineering & $-0.269 * * *$ & $(0.041)$ & & & $0.108 * * *$ & $(0.032)$ & $0.099 * *$ & $(0.031)$ & & & & & $0.098 * *$ & $(0.031)$ \\
\hline Economics & $0.088^{* *}$ & $(0.032)$ & & & $0.111^{* * *}$ & $(0.032)$ & $0.107 * * *$ & $(0.033)$ & & & & & $0.106^{* * *}$ & $(0.033)$ \\
\hline Agriculture and other & 0.022 & $(0.017)$ & & & -0.018 & $(0.046)$ & -0.023 & $(0.045)$ & & & & & -0.024 & $(0.045)$ \\
\hline Social science and law & $0.077^{* * *}$ & $(0.015)$ & & & 0.050 & $(0.042)$ & 0.047 & $(0.042)$ & & & & & 0.043 & $(0.042)$ \\
\hline $\begin{array}{l}\text { Son did not repeat classes in } \\
\text { primary school }\end{array}$ & 0.026 & $(0.019)$ & & & $0.095^{* * *}$ & $(0.027)$ & $0.084 * * *$ & $(0.026)$ & & & & & $0.084 * * *$ & $(0.026)$ \\
\hline $\begin{array}{l}\text { Number of books parents read } \\
\text { Parents visit concert/museum }\end{array}$ & $0.810^{* * *}$ & $(0.122)$ & & & & & & & 0.004 & $(0.004)$ & & & -0.002 & $(0.003)$ \\
\hline regularly & $0.270^{* * *}$ & $(0.036)$ & & & & & & & $0.054^{* * *}$ & $(0.016)$ & & & 0.000 & $(0.015)$ \\
\hline SES score neighborhood & $0.548^{* * *}$ & $(0.063)$ & & & & & & & & & $0.061^{* * *}$ & $(0.009)$ & $0.033^{* * *}$ & $(0.008)$ \\
\hline R-squared & & & 0.126 & & 0.200 & & 0.214 & & 0.010 & & 0.034 & & 0.224 & \\
\hline $\mathrm{N}$ & & & 1386 & & 1386 & & 1386 & & 1386 & & 1386 & & 1386 & \\
\hline
\end{tabular}


Table A5: Accounting for the relationship between father's log earnings and son's log earnings

\begin{tabular}{|c|c|c|c|c|c|c|}
\hline & [1] & {$[2]$} & [3] & [4] & [5] & [6] \\
\hline Math performance & 0.0447 & & 0.0163 & & & 0.0149 \\
\hline Language performance & 0.0301 & & 0.0114 & & & 0.0081 \\
\hline IQ test & 0.0049 & & 0.0037 & & & 0.0037 \\
\hline Sum of cognitive skills & 0.0797 & & 0.0314 & & & 0.0267 \\
\hline Years of schooling & & 0.1074 & 0.0869 & & & 0.0869 \\
\hline \multicolumn{7}{|l|}{ Field of study (Ref. health) } \\
\hline General & & 0.0064 & 0.0053 & & & 0.0052 \\
\hline Engineering & & -0.0291 & -0.0266 & & & -0.0264 \\
\hline Economics & & 0.0098 & 0.0094 & & & 0.0093 \\
\hline Agriculture and other & & -0.0004 & -0.0005 & & & -0.0005 \\
\hline Social science and law & & 0.0039 & 0.0036 & & & 0.0033 \\
\hline Son did not repeat classes in primary school & & 0.0025 & 0.0022 & & & 0.0022 \\
\hline Sum of schooling & & 0.1005 & 0.0803 & & & 0.0800 \\
\hline Number of books parents read & & & & 0.0032 & & -0.0016 \\
\hline Parents visit concert/museum regularly & & & & 0.0146 & & 0.0000 \\
\hline Sum of cultural capital & & & & 0.0178 & & -0.0016 \\
\hline SES score neighborhood & & & & & 0.0334 & 0.0181 \\
\hline Sum of social capital & & & & & 0.0334 & 0.0181 \\
\hline Explained & $\mathbf{0 . 0 7 9 7}(33 \%)$ & $0.1005(42 \%)$ & $\mathbf{0 . 1 1 1 7}(47 \%)$ & $0.0178(7 \%)$ & $\mathbf{0 . 0 3 3 4}(14 \%)$ & $0.1232(52 \%)$ \\
\hline Unexplained & 0.1593 & 0.1385 & 0.1273 & 0.2212 & 0.2056 & 0.1158 \\
\hline 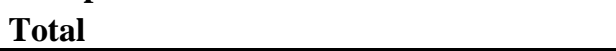 & 0.2390 & 0.2390 & 0.2390 & 0.2390 & 0.2390 & 0.2390 \\
\hline
\end{tabular}

